\title{
Pandemic, informality, and vulnerability \\ Impact of COVID-19 on livelihoods in India
}

\author{
Working Paper \\ Author(s): \\ Kesar, Surbhi; Abraham, Rosa; Lahoti, Rahul; Nath, Paaritosh; Basole, Amit \\ Publication date: \\ 2020-06 \\ Permanent link: \\ https://doi.org/10.3929/ethz-b-000428008 \\ Rights / license: \\ In Copyright - Non-Commercial Use Permitted \\ Originally published in: \\ CSE Working Paper 2020-01
}




\section{CSE Working Paper} 2020-01

\section{Pandemic, informality, and vulnerability:} Impact of COVID-19 on livelihoods in India

Surbhi Kesar, Rosa Abraham, Rahul Lahoti, Paaritosh Nath, Amit Basole June 2020

Centre for Sustainable Employment 


\title{
Pandemic, informality, and vulnerability: Impact of COVID-19 on livelihoods in India
}

\author{
Surbhi Kesar ${ }^{\mathrm{a}} \mathrm{c}$, Rosa Abraham ${ }^{\mathrm{a}}$, Rahul Lahoti ${ }^{\mathrm{ac}}$ d , Paaritosh Nath $^{\mathrm{c}}$, Amit Basole $^{\mathrm{c}}$ \\ Acknowledgements:
}

We are grateful to the team of researchers at the Center for Sustainable Employment at Azim Premji University who conducted the survey. The team includes Mridhula Mohan, Sanjana Rajashekar, Zaeen D'Souza, Sravan Pallapothu, Neha Joshi, and Adithi Rao. We greatly acknowledge their efforts in the project and several others who provided their valuable feedback at numerous stages of the project. We are particularly grateful to Deepti Goel, Arjun Jayadev, Rajendran Narayanan, and Anand Srivastava for several discussions and for their comments and feedback. We acknowledge Azim Premji University and the Azim Premji Philanthropic Initiatives for their support and funding for the project. We are thankful to the staff at the various civil society organizations who conducted the interviews and the numerous student volunteers from Azim Premji University. Any error is our own.

a The authors have contributed equally to the work.

b Corresponding author

Affiliation: Azim Premji University, Bengaluru

Email: kesar.surbhi.05@gmail.com

Address: Centre for Sustainable Employment, Azim Premji University, Bikkanahalli Main Rd, Sarjapura, Bengaluru, Karnataka, India - 562125

${ }^{c}$ Affiliation: Azim Premji University, Bengaluru

d Affiliation: ETH, Zurch 


\section{Abstract:}

We analyze findings from a large-scale survey of around 5000 respondents across 12 states of India to study the impact of COVID-19 pandemic containment measures (lockdown) on employment, livelihoods, food security and access to relief measures. We find a massive increase in unemployment, an equally dramatic fall in earnings among informal workers, large increases in food insecurity, depletion of savings and patchy coverage of relief measures. Two-thirds of our respondents lost work. The few informal workers who were still employed during the lockdown experienced more than a fifty percent drop in their earnings. Even among regular wage workers, half received either no salary or reduced salary during the lockdown. Almost eighty percent of surveyed households experienced a reduction in their food intake and a similar percentage of urban households did not have enough money to pay next month's rent. We also use a set of logistic regressions to identify how employment loss and food intake varies with individual and householdlevel characteristics. We find that migrants and urban Muslims are significantly worse off with respect to employment and food security. Among employment categories, self-employed workers were more food secure. The Public Distribution System (PDS) system was seen to have the widest reach among social security measures. However, even under PDS, 16 percent of vulnerable urban households did not have access to government rations. Further, half of the respondents reported not receiving any cash transfers (state or central). We conclude that much more is needed in the way of direct fiscal support that has been announced thus far by state and central governments in India. 


\section{Section I: Introduction}

The COVID-19 global pandemic and its associated containment measures have taken a heavy toll on economies and societies worldwide. In India, the sudden economy-wide lockdown imposed on March 24, 2020, lasting until May 31 was one of the largest and most stringent lockdowns in the world. The lockdown paused most economic activities and delivered a large aggregate supply and demand shock to the economy. The consequences have been unprecedented in scale and intensity, resulting in drastic devastation of livelihoods.

Two long-run structural characteristics of the Indian economy and decades of underinvestment in public goods have combined with the sudden and severe lockdown to generate widespread misery. First, for India's predominantly informal labour force, characterised by low earnings, insecure jobs, precarious working conditions, absence of social protection, and dependence on day-to-day earnings for sustenance, any stoppage of economic activity instantly destroys employment and earnings exposing them to large-scale vulnerabilities (ILO, 2018; Chen, 2012; State of Working India, 2018). Second, the lopsided nature of economic growth has widened the economic disparity, both between rich and poor states, as well as within states between the urban and rural regions (Economic Survey of India, 2018). This uneven growth process has created employment opportunities in larger cities much faster than that in smaller towns and villages. This unequal development manifests as migration flows of millions of workers across large distances (ibid), creating dense populations of the urban poor. When these long-run factors are put together with India's persistent underinvestment in health, housing and other public services (State of Working India, 2019), vulnerabilities to the present crisis become painfully clear. 
In this paper, we present findings from a survey of 4942 self-employed, casual, and regular wage workers across 12 states of India, conducted between April 13 and May 23, 2020. The survey was conducted via telephone in collaboration with civil society organisations (CSO) working in particular states and communities (see Appendix for a list of states and organisations). We administered a detailed questionnaire to respondents engaged in a wide variety of occupations, collecting information on their individual and household-level demographics, employment and earnings prior to and during the lockdown, and their access to the relief measures.

This survey is one of the few that brings together, on the one hand, a wide geographic coverage and, on the other, a detailed exploration of the impact of economic lockdown on livelihoods in India. ${ }^{\mathrm{i}}$ Our findings are more nuanced in the quantification of these impacts compared to other surveys that have evaluated the impact of the lockdown in India. These findings are critical to gauge the impact and the efficacy of government policy and relief efforts.

The survey findings suggest a massive increase in unemployment and an equally dramatic fall in earnings. Around two-thirds of our respondents lost work during the lockdown, with casual and nonagricultural self-employed workers being the worst impacted. Using a logistic regression, we find that these results are robust to inclusion of individual and household level attributes. The few informal workers continued to be employed during the lockdown witnessed their earnings drop by more than half, while half of the salaried workers received no salary or a reduction in salaries during the lockdown. An overwhelming majority of farmers could either not sell their produce or had to sell at lower prices. The crisis also exposed food insecurities, with almost 8 in 10 eating less food than before. Further, more than 60 percent of respondents in urban areas did not have enough money for a week's worth of essentials and a third of all respondents had taken a loan to cover expenses during the lockdown. We also use a set of logistic regressions to examine how the food intake varies with various 
demographic attributes and find households relying on wage employment, as well as Muslim and migrant households to be particularly likely to experience a reduction in their food intake.

The current relief level, especially direct public spending, does not appear to be in proportion to the severity of the situation on the ground since the bulk of the stimulus package focuses on increasing liquidity rather than direct spending. We find that even the announced relief measures, inadequate as they are, had not reached large sections of the economically vulnerable population.

The rest of the paper is organised as follows. In Section II, we present some relevant background literature. In Section III we discuss the details of the survey. Section IV describes the major findings from the survey focussing on the impact on work and earnings. Section V discusses the impact on households and the reach and effectiveness of relief measures. Section VI concludes.

\section{Section II: Background}

The pandemic has devastated normal life and led to a massive humanitarian crisis. The lockdowns imposed across countries as containment measures has resulted in halting of almost all economic activities in most economies across the world and has been described as the biggest global economic crisis since the Great Depression (World Bank, 2020). The World Bank forecasts that the global gross domestic product (GDP) will contract by 5.2 percent and the developing economies will contract by 2.5 percent in 2020 . This could potentially result in an increase in global poverty for the first time since 1990, pushing 60 to 100 million people into poverty (Lakner

et. al., 2020; World Bank, 2020). Other research has predicted that in the worst-case scenario about half a billion people might be pushed into poverty (Sumner et. al., 2020) and more than 300 million 
full-time jobs are expected to be lost worldwide in the second quarter of 2020 (International Labour Organization, 2020).

The lockdown imposed by the India government in response to the pandemic lasted almost two months and was among the most stringent in the world (Hale et.al., 2020). The first lockdown was announced on March 24, and was to last until April 14. It was later extended till May 3rd which was further extended to May 18th. During this period, all travel, schools, colleges, large gatherings and almost all economic activity other than a few essential services were prohibited. Limited agricultural activity and transportation of goods were allowed from April 20 in certain areas of the country that reported relatively fewer infections.

The strict lockdown has resulted in large scale economic distress and food insecurity as large sections of the population experience high vulnerability and subsist on daily earnings without any savings to tide them over the halt in economic activity (Ray and Subramanaian, 2020). The first nine weeks of the lockdown has been estimated to cost approximately ₹ 23 trillion (11.5 percent of GDP) and the Indian economy is predicted to contract by anywhere between 5 to 12.5 percent in 2020-21 (Sen, 2020).

A range of phone surveys have documented the distress in various parts of the country. ${ }^{\text {ii }}$ Between 50 to 80 percent of households have reported loss in employment, while those who retained employment have seen large declines in earnings. Some studies find that social identities such as caste, gender, and religion to be significant determinants of distress. For example, women were far less likely ( 24 percent) to retain employment than men, and disadvantaged caste groups 
more adversely impacted when compared to higher ranked caste groups (Deshpande, 2020). Later in the paper, we also explore the relevance of existing social hierarchies to understand who bears the burden of the current crisis.

Further, large scale increase in food insecurity, complete depletion of savings and largescale borrowing has been reported in some of the rapid assessments. The government has enhanced the social security support during the crisis but only a section of the respondents have received the support and the coverage of various schemes that were announced have been inadequate (Afridi et al., 2020; Totapally et. al., 2020; Indus Action, 2020; VikasAnvesh, 2020).

Surveys also reported that the migrant workers have been the worst affected. The sudden unexpected announcement of the lockdown and closure of all transportation combined with a lack of a social safety net resulted in indignities, hardship and even deaths. Migrant helplines across the country have reported more than 100,000 distress calls from people stranded at their places of work without any food or money to buy basic essentials (Stranded Workers Action Network, 2020; Actionaid, 2020; CPI(M)-CITU, 2020). Millions have walked or cycled hundreds of kilometers to reach their homes and several suffered casualties and deaths in the process (Gramvaani, 2020; Jan Sahas, 2020). Several starvation deaths have been reported from various parts of the country (Thejesh, 2020).

\section{Section III: About the survey}

We undertook a series of phone surveys to gauge the impacts of the lockdown on the livelihoods of India's workforce. Given the limitations on mobility and keeping in line with the 
physical distancing norms, all surveys were conducted telephonically. Following a set of questions on the demographic profile of the respondents and their households (age, gender, education, region, the main source of income, and household size), the survey instrument was divided into three broad sections. The first section surveyed respondent's primary work activity and earnings, before the lockdown (February was the reference month) and after the lockdown began (March 24th till survey date). The second section of the questionnaire examined household level impacts on financial and food security. Finally, the last section of the survey explored to what extent the existing social security nets as well as newly announced relief measures helped mitigate the impact of the crisis. On an average, each survey took fifteen minutes to administer.

\section{Sampling}

The sample of respondents in this study is purposive and non-random. We collaborated with nine civil society organisations (CSOs) across the country, engaged in a wide variety of activities across twelve large states in India, to reach out to about 5000 workers. ${ }^{i i i}$ Given the lockdown, we were unable to do a household listing of the areas where the survey was conducted. ${ }^{\text {iv }}$ Therefore, in order to identify the respondents for the survey, we relied on the phone databases of communities that these CSOs operate with. While random digit dialing is an often employed sampling strategy, given our focus on vulnerable communities who worked in the informal sector that are more likely to be severely affected by the lockdown, we decided against random digit dialing (RDD). RDD does not offer the flexibility to focus on only one segment of the population. Additionally, the response rates for RDD's are between 15 to 30 percent as compared to around 60 to 70 percent response rates that we expected (and achieved) through the CSO databases. The low response rates and setting up the RDD mechanism meant it would have taken a longer time to 
execute the survey. Even though using the CSO database makes our sample non-random, we ensure that the sample is geographically and occupationally diverse. Overall, our respondents were from 161 different districts across the 12 states in India and were involved in more than 50 different types of work.

The CSOs we collaborated with work with different types of vulnerable communities. These communities include women self-help groups, MGNREGA workers, farmers cultivating their own land, landless agricultural workers, tribals, urban poor, migrant workers and other marginalized groups. We employed two sampling strategies based on the organizations' database and capacity during the pandemic. Some organizations had an extensive database of households in the communities they worked with and for them, we randomly selected respondents from this database. For example, Pradan randomly selected respondents from the existing database of households in the districts they operated. Pradan conducted the survey in 120 rural blocks in 25 districts in three states (Jharkhand, Madhya Pradesh and Odisha). For selecting respondents in these three states, five villages in each block where Pradan operates were randomly selected. Households from these villages were randomly selected from the list of households the organization had in its records. We used this strategy for five organizations.

In cases where CSOs lacked a database of phone numbers, we employed a different sampling strategy. The CSOs created a purposive sample of respondents that were geographically and occupationally diverse. For example, the Center for Action and Research (CFAR) used their community workers and key informants in the communities to create a phone database of over 2000 households that spanned across six large metropolitan cities ${ }^{\mathrm{v}}$ and included between 30 to 200 
respondents from 25 different informal occupation categories. The number of selected respondents in each occupation category was proportional to the number of people working in that occupation in the organization's phone database. These selected respondents included sanitation workers, rag pickers, sex workers, domestic workers, construction workers, plumbers, carpenters, tailors, auto drivers, security guards, street vendors, garment factory workers, artisans, home-based workers and several other urban service providers. We used this sampling strategy for four CSOs.

Given the purposive nature of sampling, the findings presented here pertain only to the sample and are not representative of the larger population. The estimates are unweighted. But we have a geographically and occupationally diverse sample. The appendix presents the distribution of our sample across the major states. This is one of the largest COVID-19 surveys in India covering the impact of livelihoods and access to relief measures. Thus our results are likely to be indicative of how informal rural and urban workers in India, who constitute nearly $90 \%$ of the workforce, were impacted by the resultant lockdown.

The survey was administered by trained CSO staff from April 15th to May 15th. This period corresponds to the second lockdown which was a complete lockdown across the country. Each CSO usually conducted the survey over 7 to 10 days but over different time frames. The survey questionnaire was translated into six regional languages and we used SurveyCTO mobile application to collect data. All enumerators were trained via video-conferencing and online groups were created to provide support to enumerators. We compensated respondents for their time with a payment of ₹ 200 which was paid either via a phone recharge or transfer to their bank accounts. 
The provision of this compensation was indicated only at the end of the interview and hence was not an incentive for participation per se.

\section{Sample Statistics}

Overall our sample is made up of vulnerable households from marginalized communities who mostly work in the informal sector of the economy. Table 1 presents the descriptive statistics for the sample. We interviewed 4942 respondents out of which 53 percent were women and the average age of the respondents was 38 years. A third of the respondents were illiterate and the majority had not completed 10th grade in both rural and urban areas. About 6 in 10 respondents (58 percent) were the main income earners of the household. More than 8 in 10 male respondents (82 percent) were the main income earners of the household while only 36 percent of female respondents were the main income earners of the household (data not shown in Table). A quarter of all respondents in urban areas were migrants - 10 percent were migrants working in a different district than their native district in the same state (intra-state migrants) and 15 percent were working in a different state than their native state (inter-state migrants). About half of the respondents in Delhi were migrants with most of them being inter-state migrants.

[Table 1 here] 
Table 1: Sample statistics

\begin{tabular}{|c|c|c|c|}
\hline & Rural & Urban & Total \\
\hline \multicolumn{4}{|l|}{$\operatorname{Sex}(\%)$} \\
\hline Male & 47 & 45 & 46 \\
\hline Female & 53 & 53 & 53 \\
\hline Average age (years) & 38.4 & 38.3 & 38.3 \\
\hline Currently married (\%) & 82 & 76 & 79 \\
\hline \multicolumn{4}{|l|}{ Education (\%) } \\
\hline Not literate & 36 & 29 & 33 \\
\hline Primary (up to $5^{\text {th }} \mathrm{Std}$ ) & 14 & 19 & 16 \\
\hline Middle (up to $7^{\text {th }}$ Std) & 15 & 18 & 16 \\
\hline Secondary (up to $10^{\text {th }} \mathrm{Std}$ ) & 18 & 19 & 19 \\
\hline Higher Secondary (up to $12^{\text {th }} \mathrm{Std}$ ) & 9 & 7 & 8 \\
\hline Degree/Diploma & 9 & 8 & 8 \\
\hline Main income earner of the household (\%) & 52 & 65 & 58 \\
\hline \multicolumn{4}{|l|}{ Migrant $(\%)$} \\
\hline Not a migrant & 90 & 75 & 84 \\
\hline Intra-state migrant & 8 & 10 & 9 \\
\hline Inter-state migrant & 2 & 15 & 7 \\
\hline Region (\%) & 58 & 42 & 100 \\
\hline \multicolumn{4}{|l|}{ Caste (\%) } \\
\hline $\mathrm{SC}$ & 20 & 42 & 29 \\
\hline ST & 32 & 8 & 23 \\
\hline $\mathrm{OBC}$ & 35 & 27 & 32 \\
\hline General & 13 & 22 & 17 \\
\hline \multicolumn{4}{|l|}{ Religion (\%) } \\
\hline Hindu & 85 & 84 & 85 \\
\hline Muslim & 5 & 12 & 8 \\
\hline Others & 10 & 4 & 8 \\
\hline Average household size & 5.4 & 5.1 & 5.3 \\
\hline \multicolumn{4}{|l|}{ Main income source of the household (\%) } \\
\hline Self-employment in agriculture & 45 & 2 & 27 \\
\hline Self-employment in non-agriculture & 6 & 8 & 7 \\
\hline Regular wage/salary & 12 & 43 & 25 \\
\hline Casual labour in agriculture & 17 & 2 & 11 \\
\hline Casual labour in non-agriculture & 14 & 22 & 17 \\
\hline Other & 5 & 22 & 12 \\
\hline
\end{tabular}


Table 1: Sample statistics (continued)

\begin{tabular}{lrrr}
\hline & Rural & Urban & \multicolumn{2}{c}{ Total } \\
\hline Household income $(₹)$ in February $(\%)$ & & & \\
\hline Less than ₹2,000 & 26 & 8 & 18 \\
$₹ 2,000$ to ₹5,000 & 38 & 28 & 33 \\
$₹ 5,000$ to ₹10,000 & 24 & 42 & 32 \\
$₹ 10,000$ to ₹20,000 & 10 & 17 & 13 \\
More than ₹20,000 & 3 & 5 & 4 \\
\hline$N$ & 2850 & 2084 & 4934 \\
\hline
\end{tabular}

About six in ten respondents (58 percent) were from rural areas. About one in three respondents were scheduled caste, a similar proportion was from other backward caste and 23 percent were scheduled tribes. The proportion of scheduled tribes in rural areas is more since the rural districts in Jharkhand, Odisha and Madhya Pradesh where respondents were interviewed have a high proportion of tribals. The proportion of scheduled caste in urban areas is higher than the national average. This is because our urban CSOs worked with sanitation workers and rag pickers, and these groups tend to be dominated by scheduled castes. 85 percent of all respondents were Hindus, and 8 percent each were Muslims and other religions. The main source of income for households in rural areas was agriculture and in urban areas, monthly wage employment was the main source of household income. More than eight in ten households in the sample had an income of ₹ 10,000 or less in February. Urban households on average had higher incomes than rural households.

Table 2 shows how baseline household income categories were distributed across the various identity groups. Women respondents came from households that had lower incomes. More educated respondents were from households that had higher incomes. Scheduled Tribe households were among the poorest, especially in rural areas. Casual workers, particularly in agriculture, were 
among the poorest groups. Migrants, particularly inter-state migrants, had higher monthly incomes in February as compared to non-migrant households.

Table 2: Household income (₹) by identity (\%)

\begin{tabular}{|c|c|c|c|c|c|c|}
\hline & \multicolumn{3}{|c|}{ Rural } & \multicolumn{3}{|c|}{ Urban } \\
\hline & $\begin{array}{l}\text { Less than } \\
₹ 2000\end{array}$ & $\begin{array}{l}\text { ₹2000 to } \\
₹ 10000\end{array}$ & >₹10000 & $\begin{array}{l}\text { Less than } \\
\text { ₹ } 2000\end{array}$ & $\begin{array}{l}₹ 2000 \text { to } \\
₹ 10000\end{array}$ & >₹10000 \\
\hline \multicolumn{7}{|l|}{ Sex } \\
\hline Male & 19 & 62 & 19 & 6 & 61 & 33 \\
\hline Female & 32 & 60 & 8 & 9 & 79 & 11 \\
\hline \multicolumn{7}{|l|}{ Education } \\
\hline 10th Grade or below & 28 & 62 & 10 & 8 & 74 & 17 \\
\hline 11th and 12th Grade & 17 & 60 & 23 & 6 & 61 & 34 \\
\hline Degree/Diploma & 8 & 59 & 34 & 5 & 35 & 59 \\
\hline \multicolumn{7}{|l|}{ Caste } \\
\hline $\mathrm{SC}$ & 21 & 69 & 10 & 9 & 75 & 17 \\
\hline ST & 35 & 55 & 9 & 12 & 69 & 18 \\
\hline OBC & 20 & 65 & 14 & 8 & 67 & 25 \\
\hline General & 23 & 56 & 21 & 8 & 62 & 31 \\
\hline \multicolumn{7}{|l|}{ Religion } \\
\hline Hindu & 24 & 63 & 13 & 8 & 70 & 22 \\
\hline Muslim & 29 & 50 & 21 & 8 & 70 & 23 \\
\hline Other & 29 & 57 & 13 & 7 & 73 & 20 \\
\hline \multicolumn{7}{|l|}{ Main income source of household } \\
\hline Self-employment in agriculture & 30 & 57 & 13 & 10 & 45 & 45 \\
\hline $\begin{array}{l}\text { Self- employment in non- } \\
\text { agriculture }\end{array}$ & 19 & 60 & 21 & 8 & 57 & 35 \\
\hline Regular wage/salaried & 14 & 61 & 24 & 6 & 70 & 24 \\
\hline Casual labour in agriculture & 27 & 68 & 4 & 13 & 76 & 11 \\
\hline Casual labour in non-agriculture & 24 & 64 & 12 & 7 & 72 & 22 \\
\hline Other & 21 & 66 & 12 & 11 & 77 & 12 \\
\hline \multicolumn{7}{|l|}{ Migrant } \\
\hline Not a migrant & 26 & 63 & 11 & 9 & 74 & 18 \\
\hline Intra-state migrant & 36 & 49 & 15 & 10 & 69 & 21 \\
\hline Inter-state migrant & 8 & 52 & 40 & 4 & 60 & 36 \\
\hline Total & 26 & 62 & 12 & 8 & 72 & 20 \\
\hline$N$ & 644 & 1522 & 289 & 154 & 1370 & 389 \\
\hline
\end{tabular}


We identified workers in terms of four types of activities - self-employed workers operating their own farm or business; casual wage workers paid on a weekly or daily basis; regular salaried workers who received a fixed monthly payment, and unpaid family labour working on family enterprises. These categories are the same as those used by the National Sample Survey Organisation (NSSO). The profile of male and female workers in rural and urban areas is shown in Table 3. In rural areas, women were primarily engaged in agricultural work as farmers (35 percent) or casual wage workers (18 percent). About 25 percent of rural women were engaged in casual non-agricultural wage work. In urban areas, 40 percent of women respondents were engaged as salaried workers in jobs that provide a regular monthly pay or stipend (including working as domestic helpers, garment factory workers). Among men in rural areas, 42 percent were employed in casual wage work and 30 percent were working as farmers. In urban areas, nearly half of the male respondents were casual daily wage workers (48 percent) in construction and services sectors and around 31 percent worked in salaried jobs, while another 16 percent were self-employed.

Table 3: Pre-lockdown work status by region and sex (\%)

\begin{tabular}{lrrrr}
\hline & \multicolumn{2}{c}{ Rural } & \multicolumn{2}{c}{ Urban } \\
\hline Self-employed in agriculture & Male & Female & Female \\
Self-employed in non-agriculture & 30 & 35 & 1 & 0 \\
Regular wage/salaried & 10 & 6 & 15 & 15 \\
Casual workers in agriculture & 11 & 8 & 31 & 40 \\
Casual workers in non-agriculture & 16 & 18 & 1 & 0 \\
Unemployed & 26 & 25 & 48 & 39 \\
Out of labour force & 5 & 4 & 3 & 3 \\
$N$ & 2 & 4 & 1 & 3 \\
\hline
\end{tabular}

We note that even among the salaried workers, the nature of employment was precarious and vulnerable. Regular salaried work is only regular to the extent that workers were assured of the monthly payment that was due to them at the end of the month. But most such work often had no 
security, no fixed employer, and could be terminated at any point. Thus, as stated earlier, our sample mainly consists of informal workers.

\section{Section IV: Impact on employment and earnings}

\section{Employment loss}

Given the predominance of informal production and labour relations in the Indian economy (and particularly so in this sample), a cessation of all economic activity is likely to have severe impacts on employment and earnings. In this subsection, we quantify the extent of this impact using the information on workers' activities and earnings prior to and during the lockdown.

We start by noting that the unemployment rate, as usually defined, is not an appropriate measure under these circumstances. First, self-employed workers, despite suffering a shock in their earnings and work, might continue to identify themselves as self-employed (and therefore in the workforce) even if they do not work for even a single day during this period. Second, individuals losing jobs (particularly women) may report themselves as engaged in domestic responsibilities in the immediate aftermath, rather than as actively seeking employment (and hence unemployed). Therefore, in our measure we quantify employment loss as the share of workers who were in the workforce in the month of February, but reported as being either unemployed, out of the labour force (e.g. in domestic work) or not having worked for even a single day during this period. Regular salaried workers who did not work during this period but received salaries were counted as being employed.

Using this understanding of employment loss, we find that around two-thirds (sixty-six percent) of the workforce in our sample lost employment during the lockdown, with the impact being more severe in urban areas. Excluding farmers, around three-fourth of workers (self- 
employed as well as wage) suffered a loss in employment. Those self-employed in agriculture were the least affected, while the urban self-employed were the worst affected with nearly 90 percent of respondents reporting loss of employment (Figure 1).

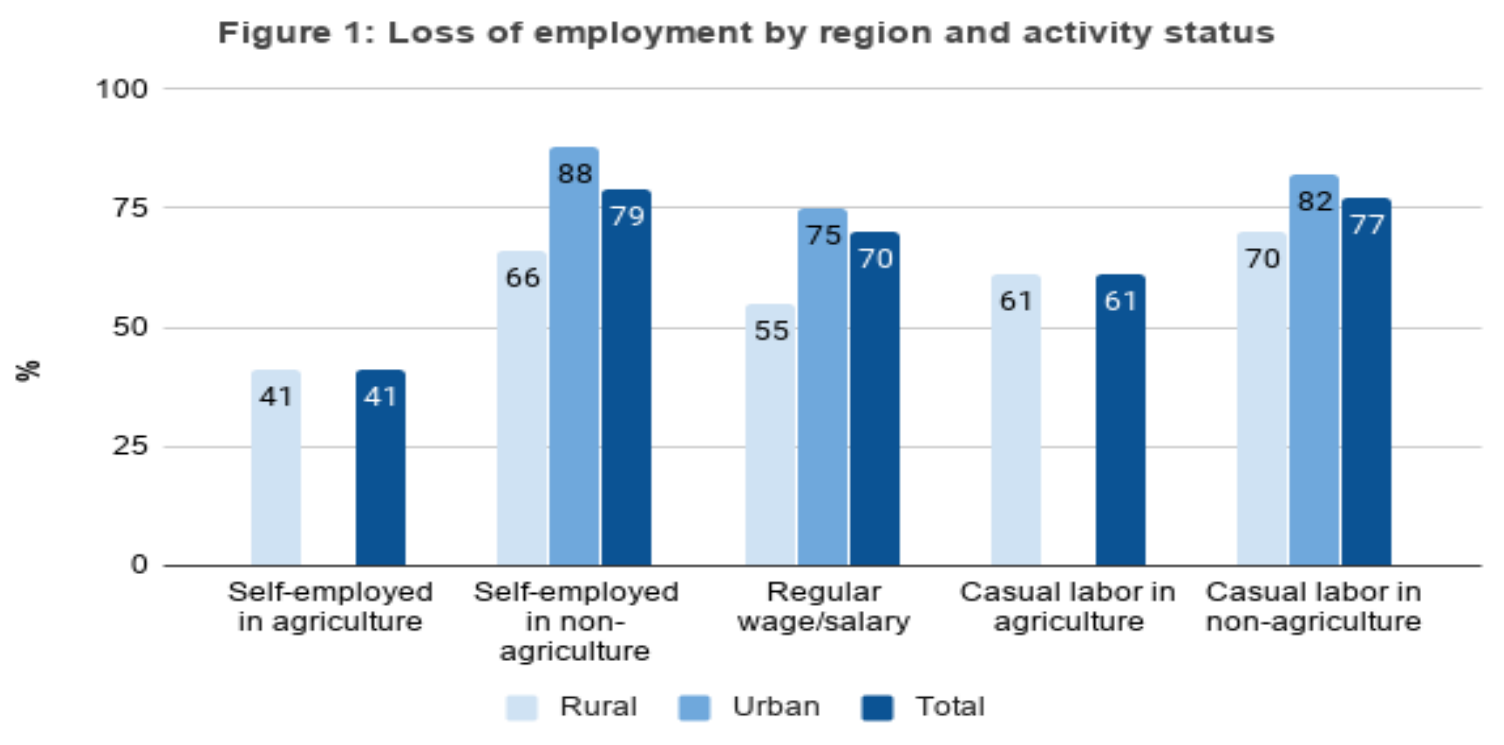

$\mathrm{N}=4529$

Next, we report loss of employment for various social identities and groups (Table 4). Women report higher loss of employment relative to men. While this is in line with our prior expectations given higher levels of informality and vulnerability among women workers, the effect for caste is not along the expected lines. A higher proportion of lower caste groups [Scheduled Castes (SC), Scheduled Tribes (ST), and Other Backward Class (OBC)] reported working during the lockdown than upper castes. A possible reason for this is that the majority of our respondents come from households earning less than ₹ 20,000 a month, indicating that forward caste households, which are more likely to belong to the upper income class and with formal jobs, are not a significant part of the sample. Further, lower caste groups may tend to work in occupations such as sanitation work or other casual work that were required to function to an extent during the 
lockdown. Furthermore, Muslim respondents were also more likely to have lost work (84 percent) compared to Hindus (66 percent). As expected, those with lesser education as well as migrants were more likely to lose work. We also find that apart from the agricultural sector, employment loss is lowest among sectors that were essential or those associated with more formal employment types, such as health and public administration.

Table 4: Loss of employment by social identities and groups (\%)

\begin{tabular}{|c|c|c|c|}
\hline \multirow[b]{2}{*}{ Sex } & \multirow[t]{2}{*}{ Rural } & \multirow[t]{2}{*}{ Urban } & otal \\
\hline & & & \\
\hline Male & 54 & 78 & 64 \\
\hline Female & 58 & 81 & 68 \\
\hline \multicolumn{4}{|l|}{ Caste } \\
\hline $\mathrm{SC}$ & 61 & 78 & 71 \\
\hline ST & 55 & 78 & 58 \\
\hline OBC & 51 & 76 & 60 \\
\hline General & 64 & 85 & 76 \\
\hline \multicolumn{4}{|l|}{ Religion } \\
\hline Hindu & 56 & 80 & 66 \\
\hline Muslim & 75 & 89 & 84 \\
\hline Others & 55 & 62 & 56 \\
\hline \multicolumn{4}{|l|}{ Education } \\
\hline $10^{\text {th }} \mathrm{Std}$ or below & 57 & 82 & 68 \\
\hline $11^{\text {th }}$ Std or 12 th Std & 55 & 79 & 63 \\
\hline Degree/Diploma & 55 & 74 & 62 \\
\hline Migrant & 72 & 84 & 80 \\
\hline \multicolumn{4}{|l|}{ Household income (₹) in February } \\
\hline Below ₹2,000 & 61 & 83 & 66 \\
\hline ₹2,000 to ₹ 10,000 & 56 & 81 & 68 \\
\hline More than ₹ 10,000 & 55 & 74 & 66 \\
\hline \multicolumn{4}{|l|}{ Sector } \\
\hline Agriculture & 49 & & 49 \\
\hline Manufacturing & 67 & 89 & 80 \\
\hline Construction & 77 & 85 & 82 \\
\hline Public Administration, Education and Health & 40 & 37 & 39 \\
\hline Other Services & 64 & 80 & 75 \\
\hline$N$ & 2590 & 1938 & 4528 \\
\hline
\end{tabular}


Effects of the lockdown have been particularly severe on India's migrant workers. The crisis exposed the vulnerable conditions under which migrants live and work, their lack of access to social protection programmes and the paucity of official information on their numbers (Stranded Workers Action Network, 2020). Three-fourth of all migrants had been working in non-native districts for more than a year (Table 5). Urban and intra-state migrants were more likely to be long term migrants than rural and inter-state migrants. Intra-state migrants were far more likely to have returned to their native place when we interviewed them as compared to inter-state migrants (55 percent versus 21 percent). A third of inter-state migrants were unable to return home due to the lockdown. At the time of the interview, about seven in ten migrants wanted to return to the place of work after the lockdown was lifted either immediately or after a few months, exposing the lack of employment opportunities in their native places. The views on whether to return to work in destination districts are likely to change as the pandemic and lockdowns continue.

Table 5: Characteristics of migrant workers (\%)

\begin{tabular}{lrrrrrrr}
\hline & \multicolumn{1}{c}{ Intra-state migrants } & \multicolumn{4}{c}{ Inter-state migrants } \\
\hline & Rural & Urban & Total & Rural & Urban & Total \\
\hline Duration of work & & & & & & \\
\hline Less than a year & 33 & 16 & 25 & 58 & 20 & 25 \\
More than a year & 67 & 84 & 75 & 42 & 80 & 75 \\
\hline Plans on returning home & & & & & & \\
\hline Returned or on my way & 75 & 32 & 55 & 44 & 18 & 21 \\
Could not return & 16 & 24 & 20 & 40 & 33 & 34 \\
Not planning to go back & 8 & 44 & 26 & 16 & 50 & 45 \\
\hline Plans on returning back to work & & & & & & \\
\hline Yes will return & 71 & 56 & 67 & 50 & 76 & 69 \\
No, will not return & 14 & 11 & 13 & 28 & 8 & 13 \\
I do not know & 15 & 33 & 20 & 22 & 16 & 18 \\
\hline Lost Employment & 68 & 82 & 75 & 92 & 85 & 86 \\
\hline$N$ & 226 & 43 & 269 & 207 & 280 & 487 \\
\hline
\end{tabular}


The above descriptive analysis points to differential effects of social identity on employment loss. To further explore some of the relations we observed above, here we estimate a multivariate logistic regression model using maximum likelihood estimation to understand how employment loss varies with individual characteristics. The dependent variable takes the value of 1 if an individual continued to work during the lockdown and 0 if they did not work. We regress this variable on individual attributes including the nature of work they are engaged in (selfemployed, casual wage or regular salaried), the sector of employment, their gender, education, religious and caste identity. We also include a categorical variable on household income in the month of February as a control. Since the profile of our sample varies and the sampling strategy might vary by state we employ state fixed effects to account for these differences. We have separate regressions for rural and urban areas as the impact is likely to vary by region.

Table 6 presents the results of the regressions. All estimates are reported in terms of the odds ratio. For a categorical independent variable, an odds ratio of greater than 1 implies that compared to the base category, the non-base category is more likely to continue in employment and an odds ratio less than one implies the opposite.

We find that, in the rural areas, on an average, casual wage workers were significantly less likely to continue in employment compared to the rural self-employed. This self-employed category largely comprises farmers, who were significantly less likely to experience employment loss compared to workers in constructions or in trade, hotels and transportation industries. This effect, at least in the short-term, is not surprising since farmers are likely to continue farming their own land and are less likely to report employment loss despite the lockdown. In the medium and long term, this effect might change if farmers are unable to continue farming due to constraints in access to raw materials and labour. 
In urban areas, regular salaried and casual wage workers are significantly more likely to continue in employment, compared to the self-employed. Therefore, the urban self-employed consisting largely of petty shopkeepers, street vendors, drivers, and small business owners are hardest hit compared to the wage workers in these areas. In terms of sector of employment, on an average, in urban areas, those employed in the public service, education and health sectors are significantly much more likely to continue working relative to those in the manufacturing sector. It is likely that these sectors also comprised some essential services that continued functioning in urban areas despite the lockdown.

In terms of the social identities of workers, we find that rural women were significantly more likely to experience loss of employment compared to men, supporting what we observed in the descriptive statistics. Similarly, as we noted in the descriptive statistics, we find that even after controlling for other characteristics, individuals from marginalized communities, on an average, were more likely to continue in employment. In terms of religious identity, while the likelihood of employment loss for rural Muslims was not significantly different compared to Hindus, Muslims were significantly more likely to lose employment relative to Hindus in the urban areas. In both rural and urban areas, migrant workers were more likely to experience loss in employment. This possibly indicates a higher vulnerability in their occupations as well as their exit from these jobs in their efforts to return to their native places. Finally, we find a significant income effect in rural areas, where individuals from households with higher levels of income (prior to the lockdown) were more likely to continue in employment. ${ }^{\text {vi }}$ 
Table 6: Logistic Regression Estimates of Employment Status (Odds ratio)

\begin{tabular}{|c|c|c|}
\hline & Rural & Urban \\
\hline \multicolumn{3}{|l|}{ Activity Status (Base: Self-employed) } \\
\hline Regular salaried & $\begin{array}{c}0.925 \\
(0.188)\end{array}$ & $\begin{array}{c}2.137 * * * * \\
(0.532)\end{array}$ \\
\hline Casual wage & $\begin{array}{c}0.495 * * * \\
(0.0569)\end{array}$ & $\begin{array}{l}1.533^{*} \\
(0.391)\end{array}$ \\
\hline \multicolumn{3}{|c|}{ Sector (Base: Agriculture (rural); Manufacturing (urban)) } \\
\hline Manufacturing & $\begin{array}{c}0.731 \\
(0.201)\end{array}$ & \\
\hline Construction & $\begin{array}{c}0.383 * * * \\
(0.0688)\end{array}$ & $\begin{array}{c}0.824 \\
(0.305)\end{array}$ \\
\hline Health, Education \& Public service & $\begin{array}{c}1.602 \\
(0.485)\end{array}$ & $\begin{array}{c}17.34 * * * * \\
(8.145)\end{array}$ \\
\hline Other Services & $\begin{array}{c}0.439 * * * \\
(0.0624)\end{array}$ & $\begin{array}{c}1.958 * * \\
(0.634)\end{array}$ \\
\hline \multicolumn{3}{|l|}{ Sex (Base: Male) } \\
\hline Female & $\begin{array}{c}0.757 * * * \\
(0.0816)\end{array}$ & $\begin{array}{c}0.892 \\
(0.146)\end{array}$ \\
\hline \multicolumn{3}{|l|}{ Social Caste (Base: General) } \\
\hline $\mathrm{SC}$ & $\begin{array}{c}1.443 * * \\
(0.268)\end{array}$ & $\begin{array}{l}1.497 * \\
(0.336)\end{array}$ \\
\hline ST & $\begin{array}{c}2.010 * * * \\
(0.386)\end{array}$ & $\begin{array}{l}1.796^{*} \\
(0.573)\end{array}$ \\
\hline OBC & $\begin{array}{c}1.599 * * * \\
(0.273)\end{array}$ & $\begin{array}{c}1.759 * * \\
(0.407)\end{array}$ \\
\hline \multicolumn{3}{|c|}{ Education (Base: Below higher secondary) } \\
\hline Higher secondary & $\begin{array}{c}1.163 \\
(0.203)\end{array}$ & $\begin{array}{c}0.772 \\
(0.235)\end{array}$ \\
\hline Degree/Diploma & $\begin{array}{c}0.915 \\
(0.172)\end{array}$ & $\begin{array}{c}1.158 \\
(0.360)\end{array}$ \\
\hline \multicolumn{3}{|l|}{ Religion (Base: Hindu) } \\
\hline Muslim & $\begin{array}{c}0.799 \\
(0.258)\end{array}$ & $\begin{array}{l}0.586^{*} \\
(0.174)\end{array}$ \\
\hline Others & $\begin{array}{c}1.015 \\
(0.177)\end{array}$ & $\begin{array}{c}8.987 \text { **** } \\
(3.554)\end{array}$ \\
\hline \multicolumn{3}{|c|}{ Household income category (Base: Below ₹2,000) } \\
\hline Between ₹2,000- ₹10,000 & $\begin{array}{c}1.431 * * * \\
(0.168)\end{array}$ & $\begin{array}{c}1.202 \\
(0.343)\end{array}$ \\
\hline Above ₹10,000 & $\begin{array}{l}1.449 * * \\
(0.266)\end{array}$ & $\begin{array}{c}1.711 \\
(0.561)\end{array}$ \\
\hline \multicolumn{3}{|l|}{ Migrant Status (Base: Non migrant) } \\
\hline Migrant worker & $\begin{array}{l}0.739^{*} \\
(0.131)\end{array}$ & $\begin{array}{c}0.507 \text { *** } \\
(0.104)\end{array}$ \\
\hline State fixed effects & Yes & Yes \\
\hline
\end{tabular}




\begin{tabular}{lcc}
\hline & Rural & Urban \\
\hline Constant & .969 & .105 \\
& $(.2285)$ & $(0.609)$ \\
\hline Observations & 2116 & 1437 \\
Likelihood Ratio chi-squared & 324.44 & 224.36 \\
Prob>chi-squared & 0.0000 & 0.0000 \\
\hline
\end{tabular}

Standard errors in parentheses, $*, * *, * * *$ indicate significance at $10 \%, 5 \%$ and $1 \%$.

The dependent variable takes the value of 1 if an individual continued to work during the lockdown and 0 if they did not work.

\section{Earnings loss}

The foregoing numbers on loss of employment clearly point to a large negative income shock in our sample. We now investigate the impact on the intensive margin for non-agricultural self-employed and casual workers who continued to remain employed (Table 7). ${ }^{\text {vii }}$ Across employment types and social identities, earnings fell by an enormous margin of 40 to 50 percent. Notably, 48 percent of the regular salaried workers reported either not having received any salary or a reduced salary during the lockdown period.

Table 7: Change in earnings for those still employed during the lockdown (\%)

\begin{tabular}{lcrr}
\hline & Rural & Urban & Total \\
\hline Sex & & & \\
\hline Male & -43 & -44 & -44 \\
Female & -55 & -15 & -44 \\
\hline Caste & & & \\
\hline SC & -50 & -29 & -39 \\
ST & -56 & -44 & -55 \\
OBC & -51 & -24 & -47 \\
General & -28 & -62 & -27 \\
\hline Religion & & & \\
\hline Hindu & -52 & -25 & -45 \\
Muslim & 28 & -45 & 6 \\
Others & -55 & -56 & -56 \\
\hline Status & & & \\
\hline Self-employed in non-agriculture & -63 & -41 & -54 \\
Casual worker & -43 & -30 & -37 \\
\hline N & 229 & 99 & 328 \\
\hline
\end{tabular}


Figure 2 compares weekly earnings for the month of February with weekly earnings during the lockdown for non-agricultural self-employed and casual wage workers. For clarity, the sample here has been restricted to those earning up to ₹ 10,000 per month pre-lockdown. Given that, barring a few outliers, all points on the scatter plot lie below the line of unity, it is evident that earnings have declined for the vast majority of workers who continued to work during the lockdown. We also find that the drop in earnings was experienced by workers across income levels.

Figure 2: Weekly earnings for self-employed and casual workers, prior to and during the lockdown

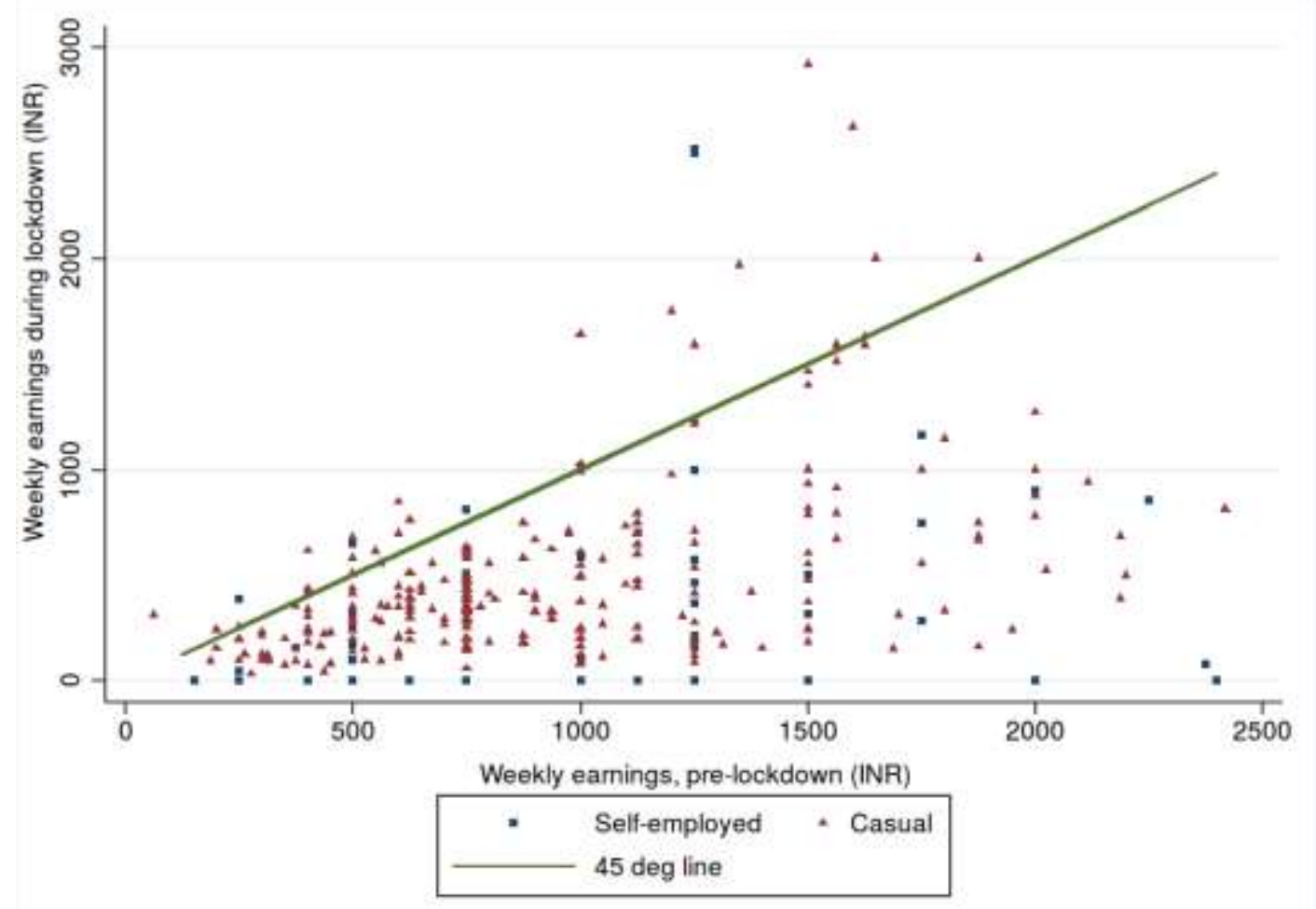

For casual workers who continued to be employed during the lockdown, this drop in earnings is partly a result of decreased availability of work and partly a fall in the wage rate. The median number of days worked per week fell from 3.75 to 1.8 (mean fell from 3.7 to 2.3 ), while the median wage rate fell by ₹ 50 (a mean fall of ₹ 80). 
While we did not collect earnings information from respondents who were self-employed in agriculture and allied activities, we asked them about difficulty in selling produce. About 6 in 10 respondents in agriculture and allied sectors had some produce to sell during the lockdown. Among those who had produce to sell an overwhelming majority ( 85 percent) could not harvest or sell or had to sell at a reduced price. The major reasons for not being able to sell were lack of transportation and lack of buyers and major reason for not being able to harvest was lack of machines or labor. The median amount they were expecting from selling the produce was ₹ 5000 . Three-fourth of farmers who sold their produce at reduced prices (40 percent of all farmers with produce) reported selling it at less than half of the normal prices.

Taken together, our findings reveal that employment and income loss are experienced across all employment categories, for men and women. Our results find resonance with what has been observed by other surveys that have studied the economic impact of COVID-19. The hardest hit were the Below Poverty Line (BPL) households with 91 percent reporting a loss in livelihood. ${ }^{\text {vii }}$ The first round of the Dalberg study across ten states revealed that 28 percent of the respondents expected a 100 percent loss of income and 45 percent of respondents expected at least a 75 percent loss in income post the lockdown (Totapally et al, 2020).

In fact, regular salaried work in India, which is seen to be relatively more secure has also experienced massive loss of employment and earnings, indicating the extent of precarity in the Indian workforce. Further, there has also been an increased informalisation and proliferation of third-party contract work even with the formal manufacturing and services sectors, making the employment arrangements even more tenuous and vulnerable. This informalisation of the formal sector has resulted in an increase in the proportion of regular salaried workers with low job security in the past two decades (State of Working India, 2018; Bhattacharya et al, 2013). The crisis 
therefore acts along this fault line of informality and has the effect of levelling-down of livelihoods across the board. This is also reflected in the apparent similarity in the relative impacts across men and women, types of workers, sectors as well as regions.

\section{Section V: Impact on households}

Money to buy essentials, food intake, and borrowing

The economic disruption from such a crisis is likely to have far-reaching consequences for households and workers beyond the immediate loss of employment and earnings. Low levels of earnings, even prior to the crisis, imply that most households have little or no savings and the slightest economic shock can expose them to food and consumption insecurity or financial indebtedness, or both. We explore this insecurity in terms of three dimensions - impact on food intake, availability of money to buy essentials, and borrowings to finance consumption.

Figure 3: Impact of lockdown on households (\%)

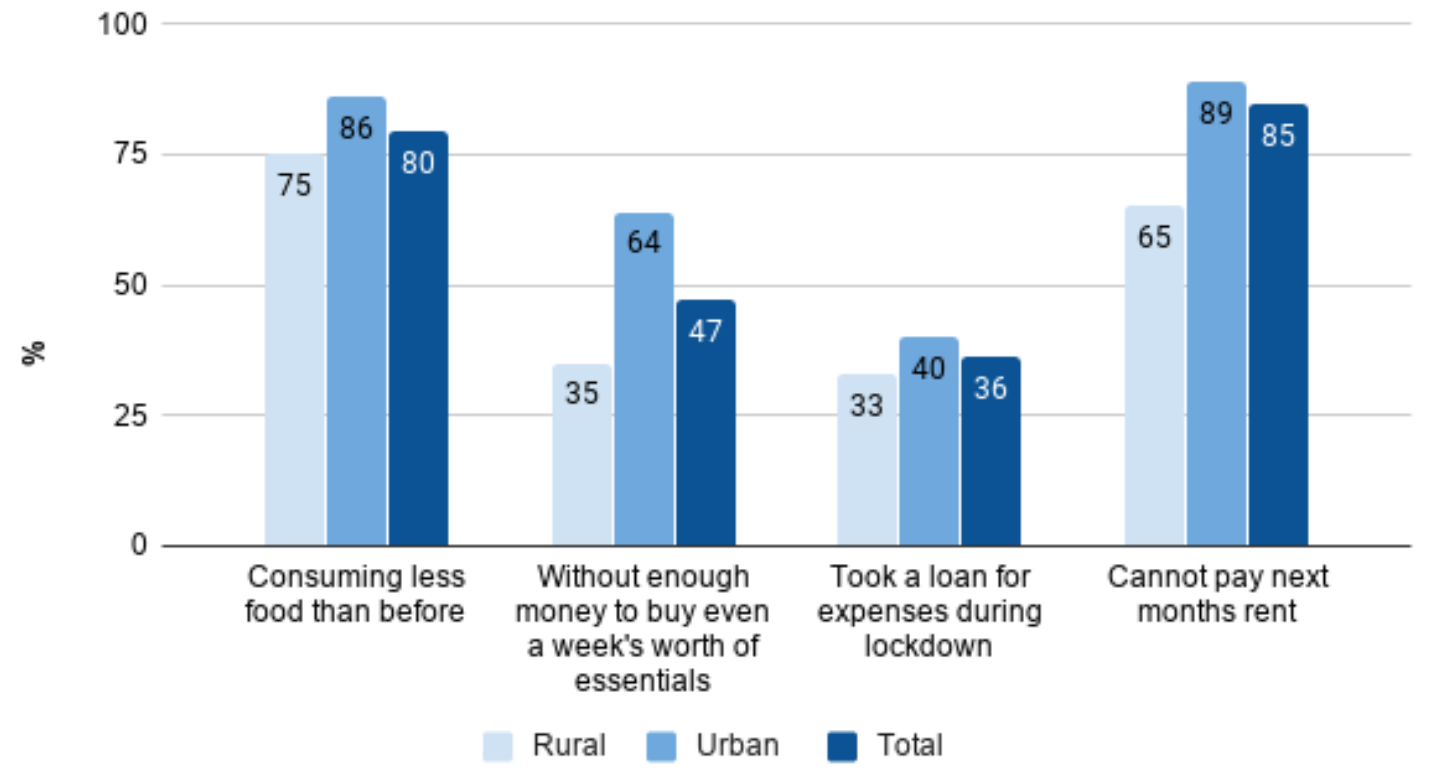


The vast majority of households reduced their food intake during the lockdown (Figure 3). The impact was particularly severe in the urban areas, with around 86 percent of households reporting a reduction in their food intake. On another indicator of vulnerability, we find that around 64 percent of urban households and 35 percent of rural households did not have enough money to buy essentials for even a week. As expected, rural and in particular, farmer households are more food secure than those involved in other activities (Table 8). While 25 percent of farmer households did not having enough money to buy more than a week's essentials and 66 percent of farmer households reported consuming less food than before the lock down far, the corresponding percentage among the non-agricultural self-employed, casual workers and even regular wage workers is much higher (over 40 percent and 80 percent, respectively).

Table 8: Impact on households by income levels and identity (\%)

Consuming less Cannot afford a week's Had to Cannot food than before worth of essentials take a loan pay rent

\begin{tabular}{lllll}
\hline Caste & & & & \\
\hline SC & 86 & 58 & 43 & 90 \\
ST & 68 & 36 & 22 & 68 \\
OBC & 77 & 43 & 38 & 79 \\
General & 84 & 48 & 40 & 88 \\
\hline Religion & & & & \\
\hline Hindu & 79 & 46 & 36 & 84 \\
Muslim & 89 & 63 & 49 & 86 \\
Others & 72 & 39 & 24 & 93 \\
\hline Migrant status & & & & \\
\hline Not a migrant & 79 & 45 & 36 & 86 \\
Intra-state migrant & 80 & 58 & 42 & 87 \\
Inter-state migrant & 88 & 64 & 28 & 87 \\
\hline Main income source of the household & & & & \\
\hline Self-employment in agriculture & 66 & 25 & 28 & 62 \\
Self-employment in non-agriculture & 81 & 44 & 38 & 75 \\
Regular wage/salaried & 83 & 57 & 37 & 87 \\
Casual labour in agriculture & 86 & 42 & 42 & 78 \\
Casual labour in non-agriculture & 86 & 58 & 40 & 86
\end{tabular}


Table 8 (continued)

\begin{tabular}{lrrrr}
\hline & $\begin{array}{c}\text { Consuming less } \\
\text { food than before }\end{array}$ & $\begin{array}{l}\text { Cannot afford a week's } \\
\text { worth ofsentials }\end{array}$ & $\begin{array}{l}\text { Had to } \\
\text { take a loan pay rent }\end{array}$ & \multicolumn{2}{c}{$\begin{array}{c}\text { Cannot } \\
\text { Other }\end{array}$} \\
\hline Household income (₹) in February & 88 & 64 & 39 & 90 \\
\hline Less than ₹2,000 & & & & \\
₹2,000 to ₹10,000 & 77 & 54 & 35 & 83 \\
More than ₹10,000 & 82 & 50 & 37 & 87 \\
\hline $\mathrm{N}$ & 69 & 34 & 33 & 79 \\
\hline
\end{tabular}

Note that this does not necessarily indicate greater incomes among farming households. It may only point to access to non-market food sources (such as own produce). Further, around 33 percent of the rural sample and around 41 percent of the urban sample reported having to take loans to cover their daily expenses during the lockdown. Here too, wage workers and nonagricultural self- employed were more likely to resort to loans, compared to farmers. Further, an overwhelming majority borrowed from informal sources such as money-lenders or friends and families. Only 4 percent of rural and 2 percent of urban households accessed formal financial institutions such as banks for loans (data not shown). Lastly, a very large proportion (90 percent) of urban respondents reported that they did not have enough money to pay next month's rent.

We observe that even among households that reported having adequate money to purchase essentials for more than a week, there was a reduction in food intake. This suggests that having resources to meet consumption requirements might only be because these consumption requirements have already been compromised in the face of the crisis. 
Household's primary income source (Base: Self-employed in agriculture (rural); Self-employed in non-agriculture (urban)

Self-employed in non-agriculture

Rural

Urban

Regular wage

0.667

$(0.176)$

0.945

$0.483 * * *$

Casual labour in agriculture

$(0.191)$

$(0.131)$

0.717

$(0.149)$

Casual labour in non-agriculture

$0.406 * * *$

$0.497 * *$

(0.0911)

(0.141)

Employment status during lockdown (Base: Continued in employment)

Lost employment

$0.331 * * * \quad-0.902 * * *$

$(0.0424)$

$(0.224)$

Gender of household's principal income earner (Base: Male)

Female principal income earner

$\begin{array}{rl}1.083 & 0.389 * * * \\ (0.164) & (0.0924)\end{array}$

Social caste (Base: General)

$\mathrm{SC}$

$1.066 \quad 1.200$

$(0.302)$

(0.341)

ST

$1.670^{*}$

1.359

$(0.458)$

(0.549)

$\mathrm{OBC}$

1.513

1.273

$(0.391)$

(0.358)

Religion (Base: Hindu)

Muslim

$0.938 \quad 0.525^{*}$

$(0.421)$

(0.183)

Religion: Others

0.781

1.364

$(0.165)$

(0.713)

Household income category (Base: Below ₹2,000)

Between ₹2,000 - ₹10,000

$\begin{array}{cc}1.025 & 1.080 \\ (0.155) & (0.408) \\ 2.065 * * * & 3.134 * * * \\ (0.451) & (1.284)\end{array}$

Migrant status (Base: Non migrant)

Migrant worker

$0.913 \quad 0.507 * * *$

$(0.201)$

(0.133)

Access to rations (Base: Procured rations)

Unable to get ration

$0.754 \quad 0.798$

(0.175) (0.227)

Did not try to get ration

$1.783 * *$

$1.964 * *$

$(0.461)$

(0.642)

Receipt of cash transfers (Base: Did not receive any transfer)

Received at least one transfer

$\begin{array}{cc}1.017 & 1.375 \\ (0.131) & (0.282) \\ \text { Yes } & \text { Yes }\end{array}$

State fixed effects 


\begin{tabular}{lcc}
\hline & Rural & Urban \\
\hline & & \\
Constant & $0.470 * *$ & $.149 * * *$ \\
& $(0.162)$ & $(0.104)$ \\
\hline Observations & 1721 & 1156 \\
Likelihood Ratio chi-squared (21) & 376 & 121.15 \\
Prob>chi-squared & 0.000 & 0.000 \\
\hline Standard errors in parentheses, *, **, *** indicate significance at 10\%, 5\% and 1\%. The dependent variable takes \\
the value 1 if the household continues to consume the same amount of food as before the lockdown and 0 if the \\
household experiences a reduction in the food intake.
\end{tabular}

In order to further explore how the food insecurity varies with the household-level characteristics, we estimate a logistic regression model. We regress the household-level characteristics on a binary response variable which takes the value 1 if the household continues to consume the same amount of food as before the lockdown and 0 if the household experiences a reduction in the food intake. The set of household-level characteristics include primary source of income of the household, work status indicating whether the respondent continued to work during the lockdown or not, gender of the principle income earner of the household, caste and religious identity of the household, household income, whether the household is migrant worker household, whether the household was able to access ration support, whether the household received an income transfer from the household. We estimate the regression using a maximum likelihood logit estimation. We run this regression separately for rural and urban regions. The results of the regression are reported as odds ratios in Table 9.

First, we find that in the urban areas, households that depend primarily on regular wage and casual wage employment are significantly more likely than those dependent on selfemployment to experience a reduction in their food intake during the lockdown. It is interesting to note that even though self-employed workers in the urban areas are most likely to lose employment 
during the lockdown, they are better off in terms of food security. In rural areas, households that depend primarily on casual wage employment in the agricultural sector are significantly more likely than households that depend on self-employment in the agricultural sector to experience a reduction in their food intake.

While there is no significant difference across caste groups, ST households in rural areas are more likely to continue with pre-lockdown consumption levels than the general caste households. In terms of the religious identity, Muslim in urban areas are significantly more likely to reduce their food intake relative to the Hindu households. This is in line with findings from other literature that highlights the higher poverty and economic vulnerability experienced by Muslims in India (Duraisamy and Duraisamy, 2017).

In this exercise, we also add the variable that captures a household's access to ration and income support. While our descriptive analysis suggests that ration and income support appears to be correlated with the food intake, the effect, even though along expected lines, is not significant once we control for the other variables in the regression.

\section{Section VI: Relief measures}

In response to the tremendous shock that the lockdown had on India's labouring poor, governments, at the Central and state levels, announced a series of relief measures ${ }^{\mathrm{ix}}$. These schemes either took the form of direct cash transfers to individuals with prior membership in existing schemes, or provision of in-kind support including rations of grains and pulses, or cooked meals in feeding centres across certain parts of the country. In this section, we examine access to these schemes in our sample and their effectiveness in dealing with vulnerabilities in the labour market. We find that while the crisis has affected almost all sections of the lower echelons of 
society in similar ways, the reach and effectiveness of relief schemes and the access to these measures have not been neutral, with certain kinds of households having an advantage in accessing schemes and relief measures.

We specifically look at the reach and efficacy of four different measures that the government used as interventions to address the crisis. For the provision of in-kind support, the government relied on one of the largest social security nets available in the country - the Public Distribution System (PDS) ${ }^{\mathrm{x}}$. The quantity of essentials supplied to eligible households under the PDS was increased with the additional quantity being provided for free. Besides the in-kind support, the government also announced cash transfers to account holders under various preexisting schemes. One such scheme, the PM-KISAN, provides income support to farmers (cultivators who own land) $^{\mathrm{xi}}$. In the wake of the crisis, the government announced the early release of payments under this scheme. Cash transfers were also announced for account holders of two other schemes - Jan Dhan and widow/pension account holders ${ }^{\mathrm{xii}}$.

Figure 4: Access to relief measures for vulnerable households (by region) (\%)

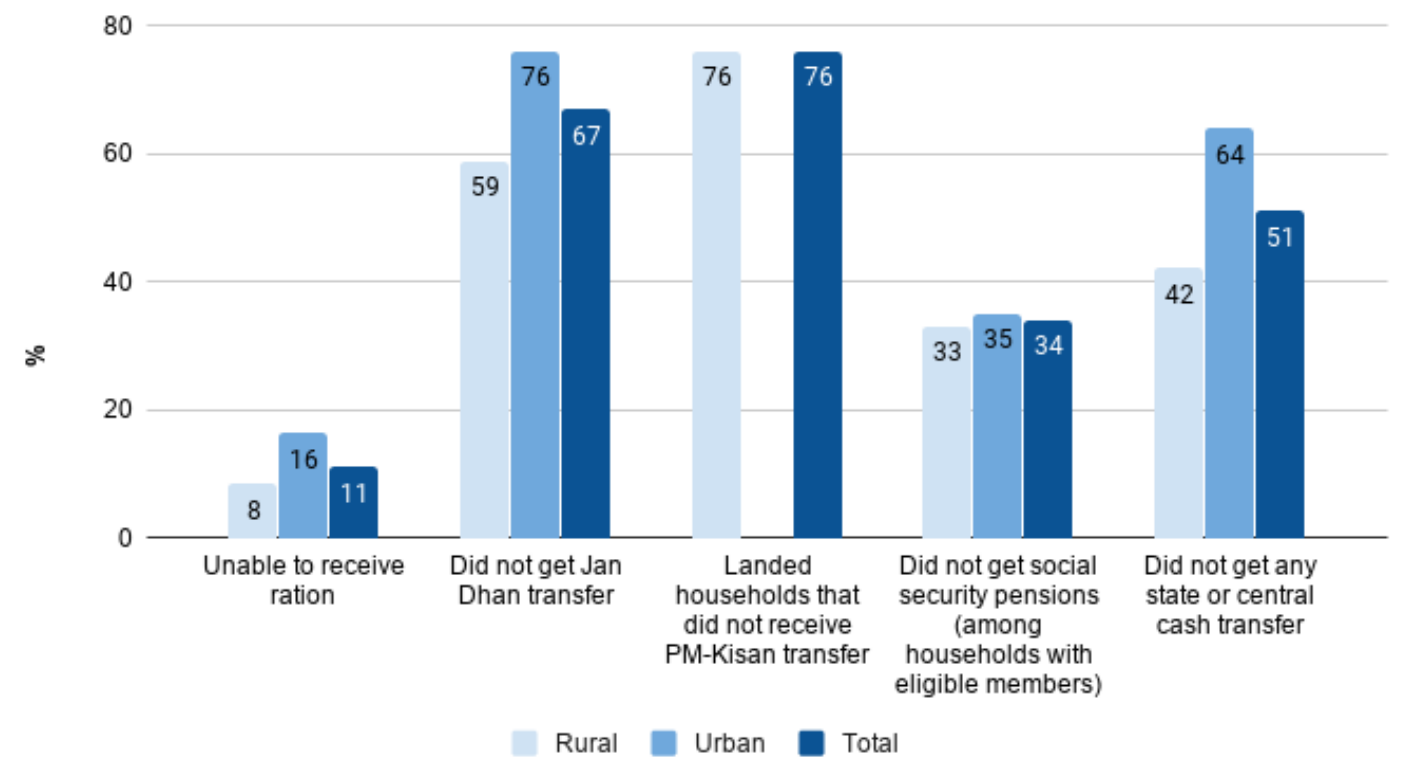


In our sample, we find that almost 89 percent of rural and 77 percent of urban households possessed a ration card needed to access the PDS. Upon excluding migrant workers (who until recently were only eligible to access PDS in their state of permanent residence), this rural-urban disparity is reduced, with around 84 percent urban non-migrant households having access to ration cards. Overall, we found that 11 percent of households were unable to receive rations during the lockdown. The performance of rural areas was better than the urban areas (Figure 4). In terms of social groups, scheduled tribe households performed the best in terms of access to these essentials (Table 10). Nearly one in five interstate migrants did not receive ration during the crisis. 92 percent of the households that earned less than ₹ 2000 in the month of February managed to receive rations during the lockdown.

Table 10: Access to relief measures for vulnerable households by identity and income of household (\%)

\begin{tabular}{|c|c|c|c|c|c|}
\hline & $\begin{array}{l}\text { Unable to } \\
\text { access ration }\end{array}$ & $\begin{array}{l}\text { Did not } \\
\text { receive Jan } \\
\text { Dhan transfer }\end{array}$ & $\begin{array}{l}\text { Did not } \\
\text { receive PM- } \\
\text { Kisan transfer }\end{array}$ & $\begin{array}{l}\text { Did not receive } \\
\text { pension } \\
\text { transfer }\end{array}$ & $\begin{array}{l}\text { Did not } \\
\text { receive any } \\
\text { cash transfer }\end{array}$ \\
\hline \multicolumn{6}{|l|}{ Caste } \\
\hline $\mathrm{SC}$ & 11 & 68 & 80 & 33 & 54 \\
\hline ST & 7 & 67 & 87 & 31 & 46 \\
\hline $\mathrm{OBC}$ & 11 & 59 & 65 & 37 & 44 \\
\hline General & 12 & 70 & 50 & 26 & 56 \\
\hline \multicolumn{6}{|l|}{ Religion } \\
\hline Hindu & 11 & 66 & 73 & 33 & 49 \\
\hline Muslim & 16 & 71 & 60 & 49 & 63 \\
\hline Others & 10 & 71 & 87 & 34 & 56 \\
\hline \multicolumn{6}{|l|}{ Migrant } \\
\hline Not a migrant & 10 & 66 & 75 & 30 & 49 \\
\hline Intra-state migrant & 10 & 75 & 85 & 47 & 59 \\
\hline Inter-state migrant & 24 & 73 & 50 & 58 & 66 \\
\hline \multicolumn{6}{|c|}{ Main income source of household } \\
\hline $\begin{array}{l}\text { Self-employed in } \\
\text { agriculture }\end{array}$ & 8 & 59 & 76 & 29 & 38 \\
\hline
\end{tabular}




\begin{tabular}{lllll} 
& Did not & Did not & Did not receive & Did not \\
Unable to & receive Jan & receive PM- & pension & receive any \\
access ration & Dhan transfer & Kisan transfer & transfer & cash transfer \\
\hline
\end{tabular}

\begin{tabular}{|c|c|c|c|c|c|}
\hline $\begin{array}{l}\text { Self-employed in } \\
\text { non-agriculture }\end{array}$ & 12 & 75 & - & 26 & 59 \\
\hline $\begin{array}{l}\text { Regular } \\
\text { wage/salaried }\end{array}$ & 15 & 74 & - & 33 & 60 \\
\hline $\begin{array}{l}\text { Casual labour in } \\
\text { agriculture }\end{array}$ & 7 & 48 & - & 35 & 39 \\
\hline $\begin{array}{l}\text { Casual labour in } \\
\text { non-agriculture }\end{array}$ & 15 & 68 & - & 43 & 55 \\
\hline Other & 12 & 78 & - & 37 & 63 \\
\hline \multicolumn{6}{|c|}{ Household incomes (₹) in February } \\
\hline Less than $₹ 2,000$ & 8 & 65 & 80 & 34 & 44 \\
\hline$₹ 2,000$ to ₹ 10,000 & 12 & 67 & 73 & 33 & 53 \\
\hline More than ₹10,000 & 14 & 74 & 76 & 34 & 57 \\
\hline $\mathrm{N}$ & 4600 & 3448 & 918 & 1264 & 4194 \\
\hline
\end{tabular}

Around 31 percent of rural respondents owned land and were eligible to receive cash under the PM-KISAN scheme. We found that there was a clear difference in the receipt of transfers by caste. Nearly nine in ten scheduled tribe households and eight in ten scheduled caste households engaged in farming did not receive the aforementioned installment. On the other hand, around half of the general category farming households did manage to receive the same.

With respect to the Jan Dhan scheme, a relatively higher percentage of Muslim households did not receive any transfer compared to Hindu households. Moreover, a lower share of migrant households received this transfer compared to non-migrant households. Households whose main source of income was agriculture (whether self-employed or casual agricultural work) were noted to be doing relatively better than the other household categories. 
Close to two-thirds of all eligible pensioners received their pension. Pensioners belonging to Muslim households fared worse off here as well with close to half of the pensioners not receiving their due pension transfer. Similarly, only 42 percent of inter-state migrants received this transfer.

In an attempt to capture the overall reach of the aforementioned cash schemes as well as that of any other cash transfer schemes announced by the state or central government, we looked at the share of households who received at least one cash benefit transfer from the government. On the whole we observed that only half of the households received any cash transfer from the government. Muslim households were least likely to receive even a single cash transfer compared to Hindus and other religious groups. Inter-state migrant households were once again the worst performers with two -thirds of such households not receiving any transfer. More than six in ten farmer households received at least one transfer,

Overall our analysis shows that using a universal scheme such as the PDS has the benefit of broader scope and of lower exclusion rates. Almost 80 percent of low-income households were able to access rations. This is in contrast to the targeted cash transfer schemes which gravely fell short of reaching its intended beneficiaries, with about half of vulnerable households not receiving even one form of cash transfer. Additionally, the targeted cash transfers have also resulted in the exclusion of already marginalised communities from the ambit of these schemes. This has implications on the nature of the recovery process. If access to relief measures are unequal, it is likely that the recovery from the crisis will also be of a selective nature, favouring certain kinds of households over others, and potentially perpetuating existing inequalities. 


\section{Section VII: Conclusion}

The foregoing results and analysis clearly show a profoundly negative impact of the COVID-19 containment measures on the Indian economy. Long-run features such as a delayed structural transformation and high levels of informal employment have combined with a severe short-run contraction of demand to destroy livelihoods on a large scale. Given precarity and absence of social security, any shock to economic production directly translates into a loss of employment, a sharp decline in earnings, and aggravation of livelihood insecurities. Low levels of earnings and the consequent lack of savings among most households magnify their food insecurity, forcing them to compromise on food intake. In our survey, these effects are seen across the board, for all work types, sectors, gender, and other identities.

The purposive nature of the sampling does not allow us to generalise the survey findings beyond the sample. Therefore, we do not make any statements regarding the entire economy purely on the basis of this survey. However, evidence that is rapidly gathering from several surveys paints a similar picture. Further, macroeconomic projections are consistent with very large negative effects. According to one estimate, the Indian Economy may contract in 2020-21 by 12.5 percent and return to pre-crisis levels of GDP only after several years (Sen, 2020).

While calls for immediate and large fiscal support measures have emerged from several quarters, current levels of fiscal support in India fall well short of what is required. For example, we show that incomes have been either wiped out or halved, resulting in lost earnings of several thousands of rupees for April and May. But the promised cash transfers (state and Centre combined) hardly compensate for this. The low reach and lack of effectiveness of the government support make it imperative for migrants to return to work. This is evident for instance from the 
fact that despite the immense hardships faced in returning home, around 47 percent responded that they would immediately return to work-sites post the lockdown.

Taken together, our findings, together with findings from other surveys point to an urgent need for a large fiscal intervention. We hope that they will bring forth a policy response appropriate in scale to this unprecedented crisis. 


\section{Works cited}

Action Aid. (2020, June). Workers in the Time of COVID 19. ActionAid, New Delhi, India. Retrieved from https://www.actionaidindia.org/wp-content/uploads/2020/05/Workers-inthe-Time-of-COVID-19-1-Rapid-Assessment-in-Bihar-Final.pdf.

Afridi, F., Dhillon, A., and Roy, S. (2020, April 23). How has Covid-19 crisis affected the urban poor? Findings from a phone survey. Ideas for India. Retrieved June 17, 2020, from https://www.ideasforindia.in/topics/poverty-inequality/how-has-covid-19-crisis-affectedthe-urban-poor-findings-from-a-phone-survey.html

Bhattacharya, R., S. Bhattacharya, and K. Sanyal. (2013). Dualism in the Informal Economy: Exploring the Indian Informal Manufacturing Sector. In Development and Sustainability: India in a Global Perspective, ed. S. Banerjee and A. Chakrabarti, 339-362. New Delhi: Springer.

Chen, M.A. (2014). Informal Employment and Development: Patterns of Inclusion and Exclusion. European Journal of Development Research, 26 (4): 397-418.

CPI(M)-CITU. (2020, April). Survey of Migrant Workers in Distress in Delhi under COVID-19 Lockdown. Retrieved from https://www.docdroid.net/uJ1YFIJ/cpim-citu-survey-ofmigrant-workers-in-delhi-24-april-2020-pdf

Deshpande, A. (2020). The Covid-19 Lockdown in India: Gender and Caste Dimensions of the First Job Losses. Working Papers 30, Ashoka University, Department of Economics, New Delhi, India.

Duraisamy, P., and Duraisamy, M. (2017). Social Identity and Wage Discrimination in the Indian Labour Market. Economic and Political Weekly, LII(4) 51-60.

Economic Survey of India. (2018). Ministry of Finance, Government of India.

Gramvaani. (2020). COVID-19 response services. Retrieved June 17, 2020, from https://gramvaani.org/?p=3631 
Indus Action. (2020, May). Month One- COVID-19 Response. Retrieved from https://cse.azimpremjiuniversity.edu.in/wp-content/uploads/2020/05/COVIDResponse Month-1-Report.pdf

International Labour Organisation. (2018, August). India Wage Report: Wage Policies for Decent Work and Inclusive Growth. Geneva: International Labour Organisation. Retrieved from https://www.ilo.org/wcmsp5/groups/public/---asia/---ro-bangkok/---sronew delhi/documents/publication/wcms 638305.pdf

International Labour Organization. (2020, May). ILO Monitor: COVID-19 and the world of work. (Fourth edition) Updated estimates and analysis. Geneva: International Labour Organsaition Retrieved from https://www.ilo.org/wcmsp5/groups/public/@dgreports/@dcomm/documents/briefingnot e/wcms 745963.pdf

Jan Sahas. (2020, April). Voices of the Invisible Citizens. New Delhi. Retrieved from https://9f10ca96-9d6f-4573-8373ed4c52ef9c6a.filesusr.com/ugd/d70f23_f18accd3b4404f789889b53fa27d99c8.pdf

Lakner, C., Mahler, D. G., Negre, M., and Beer, E. (2020). How Much Does Reducing Inequality Matter for Global Poverty?. Global Poverty Monitoring Technical Note; 13. Washington, D.C.: World Bank Group.

Lahoti, R., A. Basole, R. Abraham, S. Kesar, and P. Nath. (2020, June 5). Hunger Grows as India's Lockdown Kills Jobs Results of a Survey from 12 States. The India Forum.

Ray, D., and Subramanian, S. (2020). India's Lockdown: An Interim Report. National Bureau of Economic Research Working Paper w27282.

Sen, P. (2020, June 6). The Covid-19 shock: Learnings from the past, addressing the present - II. Ideas for India. Retrieved June 17, 2020, from https://www.ideasforindia.in/topics/macroeconomics/the-covid-19-shock-learnings-fromthe-past-addressing-the-present-ii.html 
State of Working India (2018). Centre for Sustainable Employment, Azim Premji University, Bengaluru.

State of Working India (2019). Centre for Sustainable Employment, Azim Premji University, Bengaluru.

Stranded Workers Action Network. (2020, June 5). To leave or not to leave. Retrieved June 17, 2020, from http://strandedworkers.in/mdocs-posts/to-leave-or-not-to-leave/

Sumner, A., Hoy, C., and Ortiz-Juarez, E. (2020). Estimates of the Impact of COVID-19 on Global Poverty. UNU-WIDER Working paper 43/2020.

The World Bank. (2020, June 8). The Global Economic Outlook During the COVID-19 Pandemic: A Changed World. Retrieved June 15, 2020, from https://www.worldbank.org/en/news/feature/2020/06/08/the-global-economic-outlookduring-the-covid-19-pandemic-a-changed-world

Thejesh, G. N. (2020). Non Virus Deaths. Retrieved June 17, 2020, from https://thejeshgn.com/projects/covid19-india/non-virus-deaths/

Totapally, S, et al. Dalberg, (2020). The Efficacy of Government Entitlements in Helping BPL Families Navigate the Financial Impacts of Covid-19. India Spend. Retrieved from www.indiaspend.com/wp-content/uploads/2020/04/14-April_Executive-Summary_DEAMeeting_vFINAL_HG.pdf

Hale, Thomas, Sam Webster, Anna Petherick, Toby Phillips, and Beatriz Kira (2020). Oxford COVID-19 Government Response Tracker, Blavatnik School of Government. Data use policy: Creative Commons Attribution CC BY standard.

Vikas Anvesh Foundation. (2020). COVID-19 Induced Lockdown - How is the Hinterland Coping? Retrieved June 17, 2020, from http://www.vikasanvesh.in/covid-19/ 


\section{Appendix A1}

\begin{tabular}{|c|c|c|c|c|}
\hline $\begin{array}{l}\text { States } \\
\text { Covered }\end{array}$ & Partner Organisations & $\begin{array}{l}\text { Start date of survey } \\
(M M / D D / Y Y Y Y)\end{array}$ & $\begin{array}{l}\text { End date of survey } \\
(M M / D D / Y Y Y Y)\end{array}$ & $\begin{array}{l}\text { Number of } \\
\text { respondents }\end{array}$ \\
\hline $\begin{array}{l}\text { Andhra } \\
\text { Pradesh } \\
\text { (Rural) }\end{array}$ & Samalochana & $24-04-2020$ & $05-05-2020$ & 281 \\
\hline Bihar (Rural) & $\begin{array}{l}\text { Aga Khan Rural } \\
\text { Support Programme }\end{array}$ & $17-04-2020$ & $12-05-2020$ & 184 \\
\hline Delhi (Urban) & $\begin{array}{l}\text { Centre For Advocacy } \\
\text { and Research (CFAR) }\end{array}$ & $17-04-2020$ & $14-05-2020$ & 243 \\
\hline Gujarat & $\begin{array}{l}\text { Self Employed } \\
\text { Women's Association } \\
\text { (SEWA) }\end{array}$ & $15-04-2020$ & $18-05-2020$ & 315 \\
\hline $\begin{array}{l}\text { Jharkhand } \\
\text { (Rural) }\end{array}$ & Pradan & $30-04-2020$ & $13-05-2020$ & 464 \\
\hline Karnataka & $\begin{array}{l}\text { Centre for Advocacy } \\
\text { and Research (CFAR), } \\
\text { Gauri Media Trust }\end{array}$ & $15-04-2020$ & $15-05-2020$ & 861 \\
\hline $\begin{array}{l}\text { Madhya } \\
\text { Pradesh } \\
\text { (Rural) }\end{array}$ & Pradan, Srijan & $14-04-2020$ & $23-05-2020$ & 545 \\
\hline $\begin{array}{l}\text { Maharashtra } \\
\text { (Pune) }\end{array}$ & $\begin{array}{l}\text { Centre for Advocacy } \\
\text { and Research (CFAR) }\end{array}$ & $13-04-2020$ & $22-05-2020$ & 323 \\
\hline Odisha & $\begin{array}{l}\text { Centre for Advocacy } \\
\text { and Research (CFAR), } \\
\text { Pradan }\end{array}$ & 22-04-2020 & $15-05-2020$ & 503 \\
\hline Rajasthan & $\begin{array}{l}\text { Centre for Advocacy } \\
\text { and Research (CFAR), } \\
\text { VAAGDHARA }\end{array}$ & $14-04-2020$ & $20-05-2020$ & 484 \\
\hline $\begin{array}{l}\text { Telangana } \\
\text { (Rural) }\end{array}$ & Samalochana & $15-04-2020$ & 09-05-2020 & 329 \\
\hline $\begin{array}{l}\text { West Bengal } \\
\text { (Rural) }\end{array}$ & $\begin{array}{l}\text { Paschim Banga Khet } \\
\text { Majoor Samiti }\end{array}$ & 29-04-2020 & 09-05-2020 & 195 \\
\hline Other States & $\begin{array}{l}\text { Azim Premji } \\
\text { Foundation }\end{array}$ & $13-04-2020$ & $23-05-2020$ & 212 \\
\hline Overall & & $13-04-2020$ & $23-05-2020$ & $4,939^{\text {xiii }}$ \\
\hline
\end{tabular}




\section{Endnotes}

${ }^{\mathrm{i}}$ Findings from the survey have been reported in news media and are available online at https://cse.azimpremjiuniversity.edu.in/covid19-analysis-of-impact-and-relief-measures/. Also see Lahoti et al (2020) for summary of the findings.

${ }^{\text {ii }}$ Please see https://cse.azimpremjiuniversity.edu.in/covid19-analysis-of-impact-and-reliefmeasures/\#other_surveys

iii The CSO partners include Aga Khan Rural Support Programme, Centre for Advocacy and Research (CFAR), Gauri Media Trust, Paschim Banga Khet Majoor Samiti, Pradan, Samalochana, Self Employed Women's Association, Srijan and Vaagdhara. We worked with field personnel of Azim Premji Foundation to pilot the questionnaire as well as conduct final phone surveys in a few states.

${ }^{\text {iv }}$ We could not use any administrative list such as the list of Public Distribution Scheme (PDS) beneficiaries or list of households maintained by Panchayats for different schemes as these lacked phone numbers and were not accessible to us during the lockdown.

${ }^{\mathrm{v}}$ CFAR conducted the survey in Ajmer, Bengaluru, Bhubaneshwar, Delhi, Jaipur and Pune.

${ }^{\text {vi }}$ We also additionally control for age of the worker and household size in our regression and find that our results hold.

${ }^{\text {vii }}$ Regular salaried workers are not part of this analysis because we did not collect data on their wages during the lockdown.

viii https://theprint.in/india/new-class-of-poor-emerging-after-job-losses-in-lockdown-95-8-bpl-slumfamilies-hit-study/433785/

${ }^{\text {ix }}$ Detailed information on relief measures is available here: https://covid19socialsecurity.wordpress.com/relief-measures/

${ }^{x}$ The PDS forms an integral part of India's food security infrastructure allowing ration-card holders to access subsidised food essentials including grains, pulses, sugar and oil from government-recognised shops across the country. PDS, unlike other recent social security schemes, is universal in nature and relies on self-selection of individuals to access ration through the PDS shops.

${ }^{x i}$ Under this scheme a direct cash transfers of ₹6000 per year in three installments of ₹2000 is given to all farmer households. Exclusion criteria are given here: https://pmkisan.gov.in/ xii The Jan Dhan scheme, announced as part of the government's financial inclusion programme, extended the opportunity of opening a bank account to any citizen. Any woman having a Jan Dhan account was to be provided with an immediate transfer of ₹ 1500 in three equal installments of ₹500 each. Pensioners and 
widowers who had a government-recognised pensioner/widower account were also eligible for a one time transfer of ₹ 1000 .

xiii The information on states was missing for three observations. 